\title{
CYSTIC LESIONS OF ANTERIOR MEDIASTINUM: CASE REPORT
}

Ana Lukovic ${ }^{1}$, Milos Arsenijevic ${ }^{2,3}$, Slobodan Milisavljevic ${ }^{2,3}$, Dragan Stojkovic ${ }^{3}$, Stanko Mrvic ${ }^{3}$ and Dragce Radovanovic ${ }^{2,3}$ ${ }^{1}$ University of Kragujevac, Serbia, Faculty of Medical Sciences, PHD candidate, Department of Surgery

${ }^{2}$ University of Kragujevac, Serbia, Faculty of Medical Sciences, Department of Surgery

${ }^{3}$ Clinical center "Kragujevac", Kragujevac, Serbia, Clinic for General and Thoracic Surgery

\author{
CISTICNE LEZIJE PREDNJEG MEDIJASTINUMA: \\ PRIKAZ SLUČAJA

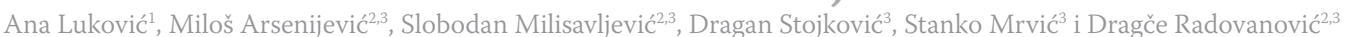 \\ ${ }^{1}$ Univerzitet u Kragujevcu, Srbija, Fakultet medicinskih nauka, Student doktorskih akademskih studija, Katedra za hirurgiju \\ ${ }^{2}$ Univerzitet u Kragujevcu, Srbija, Fakultet medicinskih nauka, Katedra za hirurgiju \\ ${ }^{3}$ Klinički centar "Kragujevac", Kragujevac, Srbija, Klinika za Opštu i grudnu hirurgiju
}

\section{ABSTRACT}

Cystic lesions of the mediastinum are uncommon, comprising $12 \%$ to $18 \%$ of all primary mediastinal tumors and unless they attain a large size and cause compressive symptoms, these tumors are generally asymptomatic and are discovered incidentally upon radiologic investigation of some other condition.

We present in this paper a case of cystic lesions of the mediastinum in a 70-year-old male patient who underwent a surgery for mediastinal mass removal. Histopathology report had shown it was the case of mature cystic teratoma of anterior mediastinum.

Based on a review of the literature, as well as our experience, we conclude that best treatment for cystic lesions of anterior mediastinum is complete surgical resection if possible.

Keywords: cystic lesions of the mediastinum, teratomas, complete surgical resection

\section{INTRODUCTION}

Germ cell tumors are uncommon neoplasms that usually arise in the gonads. The most common extragonadal site is anterior mediastinum. It is estimated that only $1-3 \%$ of all germ cell tumors arise in the mediastinum (1).

Mediastinal germ cell tumors are classified into three catagories: benign germ cell tumors, seminomas, and nonseminomatous germ cell tumors, also called malignant teratomas. Benign mediastinal teratomas accounts for $60 \%$ of all germ cell tumors and they are divided into three groups as epidermoid cysts, dermoid cysts, and teratomas (2). These tumors can characteristically be cystic or solid or a combination of the two, contain multiple germ cell layers, and are composed of tissue foreign to the organ or anatomic site in which they arise (3).

\section{SAŽETAK}

Cistične lezije medijastinuma su retke, $i$ čine oko $12 \%$ do 18\% svih primarnih tumora medijastinuma, a ukoliko ne dostignu odredjenu veličinu kada prouzrokuju kompresivne simtome, ovi tumori su asimtomatski i otkrivaju se kao usputni nalaz tokom radioloških ispitivanja drugih stanja.

$U$ ovom radu prezentujemo slučaj cistične lezije medijastinuma u pacijenta starog 70 godina, kod kojeg je uradjena hirurška intervencija $i$ uklanjanje iste u potpunosti. Rezultati histopatologije su pokazali da je u pitanju cistični teratom prednjeg medijatinuma.

$\mathrm{Na}$ osnovu literature, kao i na osnovu našeg iskustva, zaključili smo da je najbolji tretman za cistične lezije medijastinuma kompletna hirurška resekcija, ukoliko je to moguće.

Ključne reči: cistične lezije medijastinuma, teratomi, kompletna hirurška resekcija

Cystic lesions of the mediastinum are uncommon, comprising $12 \%$ to $18 \%$ of all primary mediastinal tumors and unless they attain a large size and cause compressive symptoms, these tumors are generally asymptomatic and are discovered incidentally upon radiologic investigation of some other condition $(4,5)$.

We present in this paper a case of cystic lesions of the mediastinum in a 70-year-old male patient. During the diagnostic search of dispnea and back pain, CT scan of chest was performed. It showed a large heterogeneous soft-tissue dense mass in the anterior part of the mediastinum. Patient underwent a surgery for removal of the detected mass. After performed surgery, a microscopy shown a case of mature cystic teratoma. 

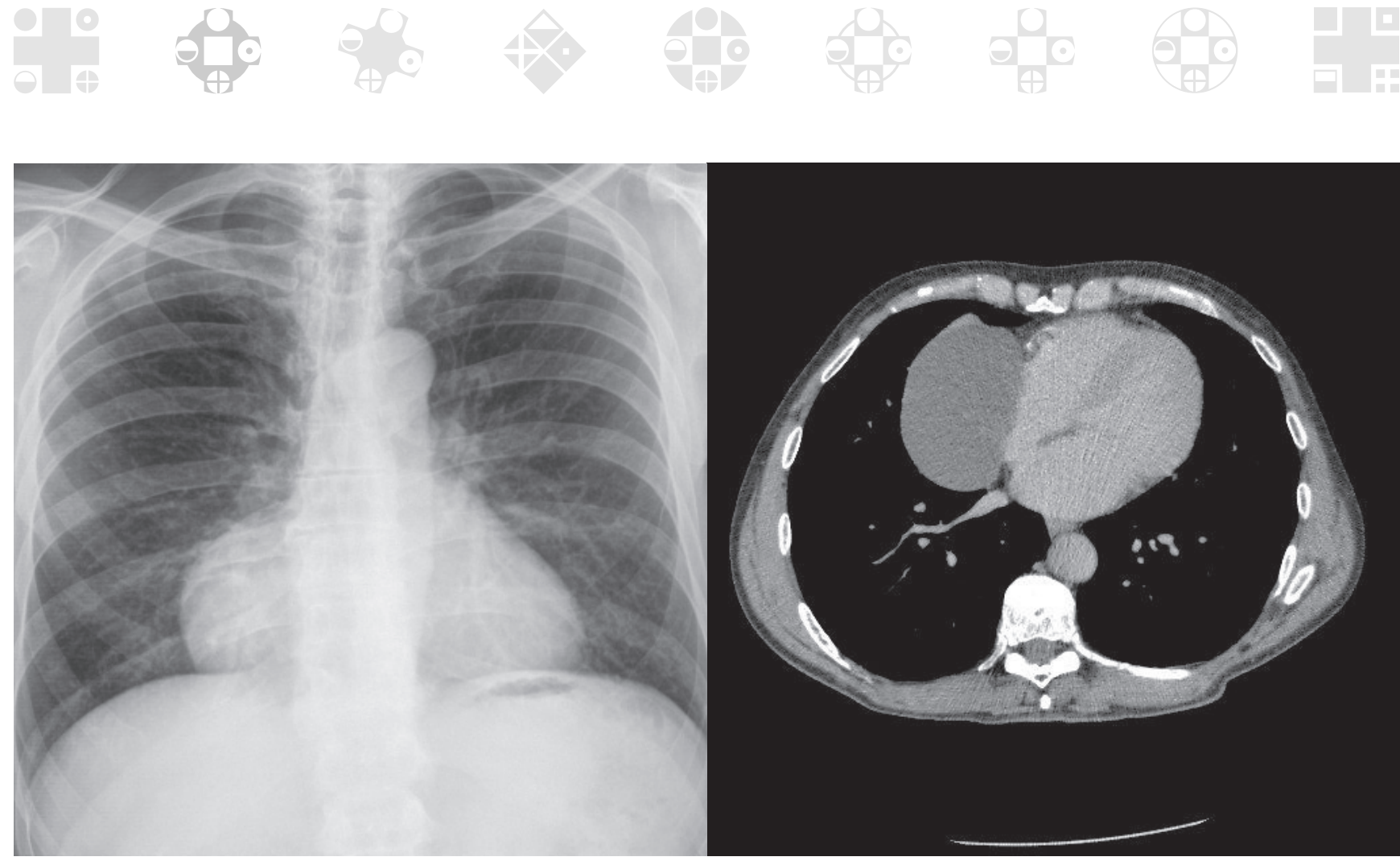

Figure 1. Left: Preoperative chest X-ray; Right: Preoperative CT chest scan of the patient

\section{REPORT OF A CASE}

A 70-year-old male presented with a mass in the anterior mediastinum. The mass was incidentally detected on a chest X-ray during the evaluation of persistent dyspnea and back pain lasting for previous three months. During his examinations, he was approached in a multidisciplinary way, and the imaging diagnosctic followed. CT scan of chest showed a large heterogeneous soft-tissue dense mass of $96 \mathrm{~mm} \times 67 \mathrm{~cm} \times 85 \mathrm{~mm}$ in the anterior mediastinum extending to right hemithorax (Fig. 1).

Based on our experience with mediastinal masses, and reviewing complete medical history, the patient was planned for complete resection. He underwent a right pos- terolateral thoracotomy through the 5th intercostal space. Intraoperatively a large cystic mass present in anterior mediastinum (Fig. 2).

With careful blunt and sharp dissection, the mass was dissected all around and was resected completely without injuring any vital structures. Apical thoracostomy tube was placed and wound was closed in layers. The patient recovered uneventfully. Serial postoperative X-rays showed a complete right lung expansion (Fig. 3). The patient was discharged from the hospital one week after the operation. Histopathology report described a mature teratoma with cystic structures.

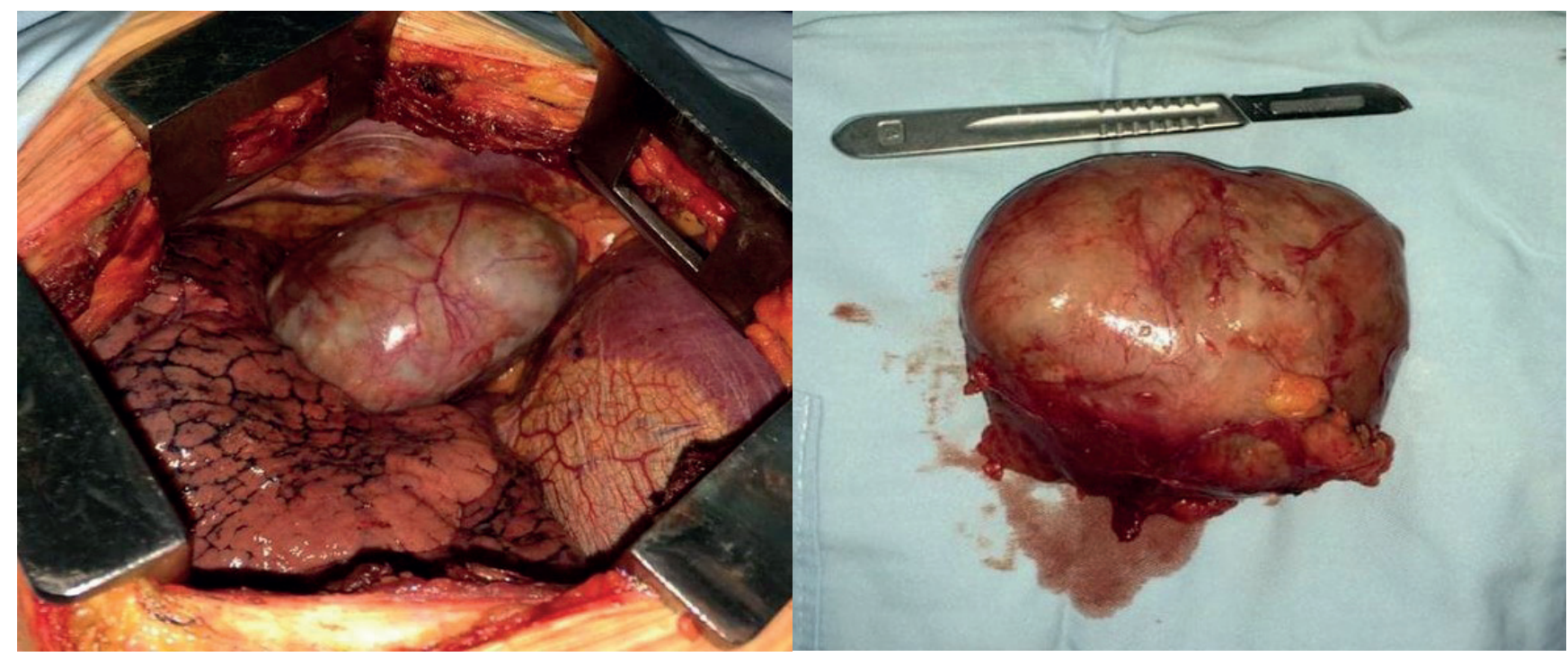

Figure 2. Left: Intraoperative finding of the mediastinal mass; Right: Extirpated mediastinal mass with surgical knife for size comparisement 


\section{DISCUSSION}

Cystic lesions of the mediastinum are uncommon, comprising $12 \%$ to $18 \%$ of all primary mediastinal tumors and unless they attain a large size and cause compressive symptoms, these tumors are generally asymptomatic and are discovered incidentally upon radiologic investigation of some other condition $(4,5)$. Mediastinal cysts can be classified on the basis of their anatomical location and histomorphology. Thus, the cysts may be found either in the superior, anterior, middle or posterior mediastinum. Histologically, they may be classified into foregut cysts, cystic teratomas, thymic cysts and a large miscellaneous group. Foregut cysts are further categorised on the basis of their anomalous embryonic origin into bronchogenic, oesophageal, gastric and undifferentiated cysts (6).

Despite this wide repertoire of location and morphology, the symptomatology is nearly identical. Chest pain is a common symptom and is thought to be result of irritation or inflammation of the parietal or mediastinal pleura. Other symptoms like cough, dyspnea and dysphagia are all considered manifestations of compression or irritation of major airways and oesophagus by the cysts. Severity would depend on the size of the lesion (7). In our case, patient had sympthoms of dispnea and back pain two months before the surgery.

Benign mediastinal teratoma accounts for $60 \%$ of all mediastinal germ cell tumors, which in turn account for $15-20 \%$ of all anterior mediastinal masses. These tumors have been described in patients with ages ranging from 7 months to 65 years, most occur in young adults, with an approximately equal incidence in males and females (8).

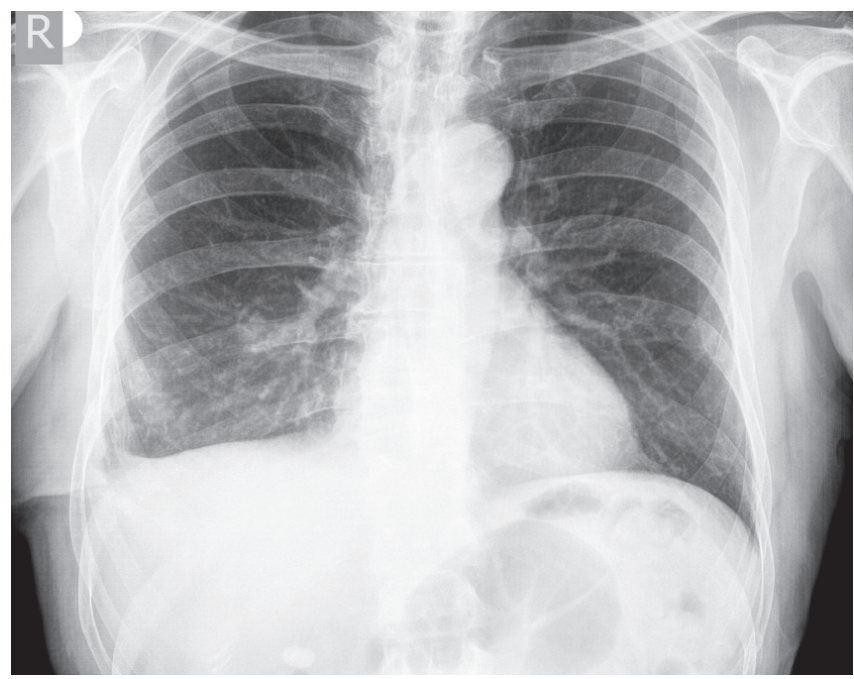

Figure 3. Postoperative chest X-ray

Mature teratomas are neoplasms derived from endodermal, mesodermal and ectodermal origin. Within the mediastinum these lesions are most commonly seen in the anterior mediastinum. Given their origin, these lesions are usually filled with sebaceous material, but may also contain macroscopic fat, bone, hair or other tissues. A small percentage may present as a primarily cystic lesion (9).

These tumors are slow growing and in recent years, 50 to $60 \%$ of patients have been asymptomatic at the time of diagnosis by routine chest radiography or other imaging diagnostical procedures. In our report that was the case. At radiography, cystic teratomas usually appear as a sharply marginated, round or lobulated anterior mediastinal mass that extends to one side of the midline. At CT scan, these

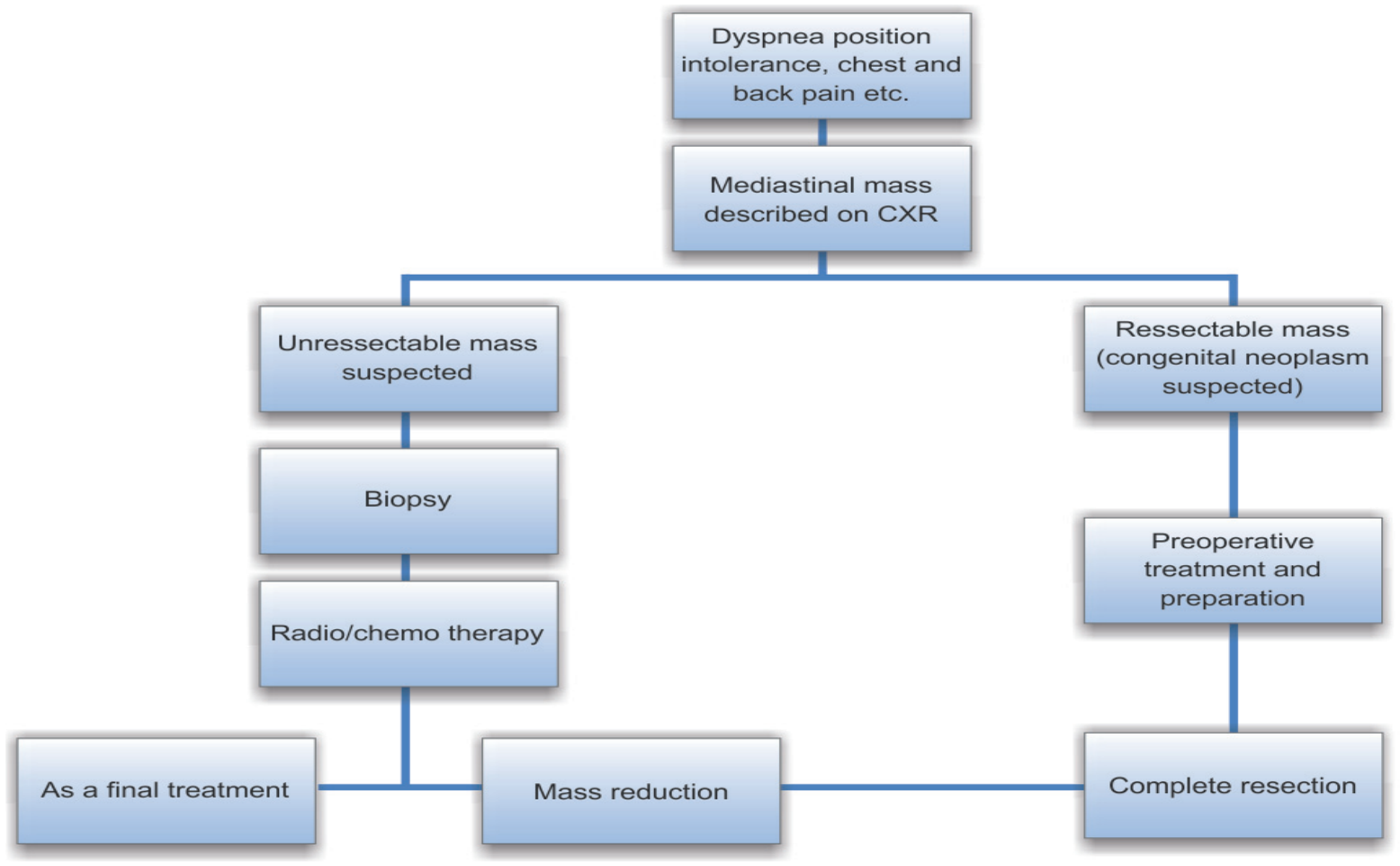

Figure 4. Short algorithm for diagnosis and treatment of mediastinal mass 
tumors are heterogeneous, well-defined masses with walls of variable thickness that may enhance. They may contain all four tissue types, including soft tissue, fluid, fat, and calcium, but fluid-containing cystic components are usually prominent (10).

Benign lesions have no sex predilection; however, malignant ones are more common in males. Mediastinal teratomas rarely produce symptoms except when they attain large size or may rupture into the lung and bronchial tree, pleural space, pericardial space, or great vessels which can lead to the life threathinig complications $(11,12,13)$.

Despite the value of various noninvasive diagnostic studies, definitive diagnosis is established only by surgical excision and tissue biopsy (Fig. 4). Transtracheal and percutaneous cystic aspirations have been proposed as alternatives to operation, but these methods are not widely accepted because of possible cystic recurrence, which carries a substantial morbidity rate or risk of complications related to the diagnostic procedure $(14,15)$.

Many of the patients who do not undergo surgery at diagnosis develop symptoms related to growth of the cyst, which means that an operation then involves a higher morbidity and mortality rate, together with a risk of malignancy and development of complications (16).

There are those who recommend conservative treatment for mediastinal cysts, on the ground that it avoids surgical morbidity and mortality. To the contrary, the prognosis after complete excision is excellent, and the morbidity and mortality rates associated with surgery are low as it was shown in our case (17).

\section{CONCLUSION}

Based on a review of the literature, as well as our experience, we conclude that best treatment for cystic lesions of anterior mediastinum is complete surgical resection if possible. Surgical procedure, if performed well, has low mortality and morbidity rates, with excellent prognosis for long term survival rate and complete treatment.

\section{REFERENCES:}

1. Anushree CN, Shanti V. Mature Mediastinal Teratoma. Journal of Clinical and Diagnostic Research: JCDR. 2015; 9(6):ED05-ED06.

2. Dalal U, Jora MS, Dalal AK, Attri AK, Singal R, Gupta S. Primary Germ Cell Tumor of the Mediastinum - Presenting as a Huge Mass. International Journal of Preventive Medicine. 2014; 5(2):230-232.
3. Zisis C, Rontogianni D, Stratakos G. Teratoma occupying the left hemithorax. World Journal of Surgical Oncology. 2005; 3:76.

4. Takeda S, Miyoshi S, Minami M, Ohta M, Masaoka A, Matsuda H. Clinical spectrum of mediastinal cysts. Chest. 2003 Jul; 124(1):125-32.

5. Esme H, Eren S, Sezer M, Solak O. Primary Mediastinal Cysts: Clinical Evaluation and Surgical Results of 32 Cases. Texas Heart Institute Journal. 2011; 38(4):371-374.

6. Ödev K, Arıbaş BK, Nayman A, Arıbaş OK, Altınok T, Küçükapan A. Imaging of Cystic and Cyst-like Lesions of the Mediastinum with Pathologic Correlation. Journal of Clinical Imaging Science. 2012; 2:33.

7. Petkar M, Vaideeswar P, Deshpande JR. Surgical pathology of cystic lesions of the mediastinum. J Postgrad Med. 2001 Oct-Dec; 47(4):235-9.

8. Lakhotia S, Dewan RK. Benign cystic teratoma of mediastinum. The Indian Journal of Surgery. 2008; 70(5):244-246.

9. Vargas D, Suby-Long T, Restrepo CS. Cystic Lesions of the Mediastinum. Semin Ultrasound CT MR. 2016 Jun; 37(3):212-22.

10. Jeung MY, Gasser B, Gangi A, Bogorin A, Charneau D, Wihlm JM, Dietemann JL, Roy C. Imaging of cystic masses of the mediastinum. Radiographics. 2002 Oct; 22 Spec No:S79-93.

11. Lee YH, Hsieh SC, Chern MS, Chan WP, Yu C. Ruptured mediastinal teratoma mimicking lung parenchymal lesion. Chin J Radiol. 2006; 31:177-81.

12. Badar F, Yasmeen S, Afroz N, Khan N, Azfar SF. Benign Mediastinal Teratoma with Intrapulmonary and Bronchial Rupture Presenting with Recurrent Hemoptysis. Iranian Journal of Radiology. 2013; 10(2):86-89.

13. Bachh AA, Haq I, Gupta R, Boinapally RM, Sudhakar S. Benign mediastinal teratoma with intrapulmonary extension presenting with trichoptysis. Respir Med CME. 2010; 3(3):189-191.

14. Suen HC, Mathisen DJ, Grillo HC, LeBlanc J, McLoud TC, Moncure AC, Hilgenberg AD. Surgical management and radiological characteristics of bronchogenic cysts. Ann Thorac Surg 1993; 55(2):476-81.

15. Sarper A, Ayten A, Golbasi I, Demircan A, Isin E. Bronchogenic Cyst. Texas Heart Institute Journal. 2003;30(2):105-108.

16. Zambudio AR, Lanzas JT, Calvo MJ, Fernández PJ, Paricio PP. Non-neoplastic mediastinal cysts. Eur J Cardiothorac Surg. 2002 Nov; 22(5):712-6

17. Takeda S, Miyoshi S, Minami M, Ohta M, Masaoka A, Matsuda H. Clinical spectrum of mediastinal cysts. Chest. 2003 Jul; 124(1):125-32 